\title{
A területi tőke koncepciója és a városi vállalkozáskutatás
}

\section{The concept of territorial capital - elements of an urban entrepreneurial environment}

\author{
CZAKÓ KATALIN, DŐRY TIBOR
}

CZAKó Katalin: PhD-hallgató, Széchenyi István Egyetem, Regionális Tudományi és Közpolitikai Tanszék, Győr; ckatalin@sze.hu

DőRY Tibor: egyetemi docens, Széchenyi István Egyetem, Vezetéstudományi és Szervezeti Kommunikáció Tanszék, Győr; doryti@sze.hu

KULCSSZAVAK: területi tőke, területi versenyképesség, regionális gazdasági növekedés, vállalkozáskutatás

ABSZTRAKT: A tanulmány kiinduló témaköre a Camagni-féle területitőke-koncepció által értelmezett endogén jellegű regionális potenciálok. Átfogó célja az innovatív keresztben felsorolt tőkeértékek szemléltetése a városi környezetben tevékenykedő vállalkozói rétegben. A területi tőke a területi versenyképességet leíró fogalom, amellyel a regionális kutatások elmúlt időszakában több nemzetközi és hazai szerző is foglalkozott. A területi tőkével kapcsolatos elemzések egy lehatárolt terület speciális értékeit értelmezik. A tanulmány gyakorlati részében a győri járműipari körzetben működő vállalkozásokat érintő felmérés eredményeit mutatjuk be. A mérés módszere egy pilot jellegü kérdőíves felmérés volt. Ennek során Győr fejlődése szempontjából olyan következtetések bontakoztak ki, amelyek további kutatása támpontokat adhat a jövőben tervezett városfejlesztési akciókhoz. Ezek az eredmények a tulajdonosi hálózatokról, a tudásteremtésről és az innovációt célzó együttműködésekről számolnak be. A tanulmány azt vizsgálja, hogy ezekben - a sok esetben immateriális jegyeket hordozó - témakörökben miként jelennek meg a Camagni által értelmezett tőkeértékek. A tanulmány három fö részre bontható. Az elméleti háttér foglalkozik a területi tőke komponenseinek elméleti osztályozásával és összegyüjti az ezzel kapcsolatos főbb megállapításokat, kritikákat. A második részben a területitőke-mátrix innovatív keresztjében elhelyezkedő tőkecsoportokat értelmezzük, és ezen belül azon komponenseket emeljük ki, amelyeket a gyakorlati kutatás keretében tovább lehet vizsgálni. A harmadik rész a győri kutatás kapcsolódó eredményeit dolgozza fel.

Katalin CZAKó: PhD student, Department of Regional Science and Public Policies, Széchenyi István University, Győr; ckatalin@sze.hu

Tibor DÖRY: associate professor, Department of Leadership and Organizational Communication, Széchenyi István University, Györ; doryti@sze.hu

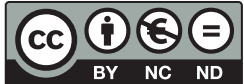


KEYWORDS: territorial capital, territorial competitiveness, regional economic growth, entrepreneurship

ABSTRACT: The point of departure is the nature of endogenous potentials as interpreted by Roberto Camagni's concept of the territorial capital. The overall objective of the study is to present the highlighted capital values of the "innovative cross" in an urban business environment. Territorial capital describes territorial competitiveness. Several authors deal with its endogenous regional elements. Each territorial capital analysis interprets this concept as territorial values in a special context.

In the practical part of the study we present the results of a survey conducted among businesses in a Hungarian middle city, Györ, and its "automotive" agglomeration. The survey was based on a pilot questionnaire. In the light of Györ's development we present territorial values, which after some more detailed research may provide some benchmark figures for future actions toward urban development. These results are mainly about ownership relations, $R \& D$ cooperation and collective activities. The study examines how these - in many cases intangible - values appear as "Camagni theoretical capital elements".

Based on this, the study can be divided into three main parts. A presentation of the theoretical background introduces the theoretical classification of territorial capital and encompasses key findings and some critical reviews. The second part follows this method and highlights the components within the "innovative cross", which we try to identify, using the research findings. This test is important because capital elements of the "innovative cross" generate regional knowledge transfer and innovation. These elements are essential to an innovative milieu in any given territory. The third part is about processing the results of the above mentioned survey.

According to our findings we can say, that the overall characteristic of the territorial capital concept can be only partially applied when analysing real-life territories with special capital components. Moreover, we can see the multi-interpretation effect already on the theoretical level as well. In spite of this, Camagni's concept of separating capital elements of the "innovative cross" is novel and useful. Due to this, several authors started to emphasize these innovative elements. This can be a key point in future regional development processes and can provide a theoretical foundation for further research of each capital components. At the same time it seems to be clear that this concept cannot be used as a tool yet, neither in the case of overall measurement of regional competitiveness nor in the case of producing an overall and comparable value map in any given region.

\section{Bevezetés}

A helyi gazdaságfejlesztés témakörében a csomóponti régió definíciója került előtérbe. A gazdasági folyamatok városi térségekben zajlanak, és gyakran túllépik a tervezési határokat (Bajmócy 2011). A Magyarországon működő feldolgozóipari csomópontok részletes elemzése, az endogén fejlödési súlypontok kiemelése megjelenik a regionális tudomány területén is (Lengyel, Szakálné Kanó, Vas 2015). E tanulmányban hangsúlyozzuk az endogén fejlődés fontosságát, és ezen belül a helyi vállalati réteg speciális értékeinek kialakulását. A bemutatott elméleti koncepció (Camagni 2008, 2009) további értelmezését az indokolja, hogy egy fejlődő városi térségben a speciális területi tőkeértékek jelentősek, ezeket a helyi szereplők alakíthatják. A cikkben a Győr és környékén működő vállalkozók területi tőkeértékekkel való jellemzését mutatjuk be. A ku- 
tatás motivációját az adta, hogy Győr és térsége a hazai járműgyártás jelentős központjává vált, kiépült szolgáltatói rendszerrel és folyamatosan bővülő gazdasági bázissal rendelkezik. A város fejlődési iránya és üteme sajátosnak tekinthető az innováció folyamatos jelenlétének és az alkalmazkodó városi funkcióknak köszönhetően (Rechnitzer 2013). Ez a folyamat hosszú múltra tekint vissza. Az 1990-es évek elején a járműipari befektetők már használhatták a kiépített ipari infrastruktúrát a Győri Nemzetközi Ipari Parkban, a szakképzett munkaerő is jelen volt a térségben a vagongyárnak ${ }^{1}$ köszönhetően. A Győr vállalati szférájában megtalálható speciális fejlődési tényezők kutatását használtuk fel a területitőke-koncepció innovatív keresztjének értelmezéséhez.

A tanulmány első részében a területi tőke komponenseinek elméleti osztályozásából indulunk ki, kiemeljük az innovatív kereszt fogalmának a magyar és a nemzetközi szakirodalomban megjelent főbb értelmezéseit és kritikáit. A témakörrel kapcsolatos vita több szempontú és folyamatos (Czakó 2015). A tanulmány második részében az innovatív kereszt tőkecsoportjainak értelmezésével foglalkozunk. Azt vizsgáljuk, hogy a felsorolt tőkeértékek miképpen jelennek meg a helyi gazdasági szereplők környezetében. Az innovatív keresztben lévő tőkecsoportok tőkeértékeit a 2014-ben elvégzett győri kutatás alapján tovább lehet elemezni, városi szinten is. A tanulmány harmadik része a kiemelt tőkeértékekhez kapcsolt kutatási eredményeket rendszerezi. A tanulmány átfogó célja az innovatív keresztben lévő tőkeértékek megjelenési formáinak szemléltetése a városi környezetben tevékenykedő vállalkozói rétegben.

\section{A területi tőke koncepciójának értelmezései}

\section{A regionális potenciálok újszerü értelmezése}

Az utóbbi idők területitőke-modelljeiben és a módszertani leírásokban számos olyan elem található, melyek komplexebb képet adhatnak egy terület gazdaságáról, az immateriális javakat is számba véve egy-egy terület értékeinek leírásakor (Zonneveld, Waterhout 2005, 2010). ${ }^{2}$ Általában a GDP-mutatókat használják a területek közti különbségek mérésére. Kizárólag ezek a számok azonban nem mutatják a tényleges helyzetképet. Vannak olyan időszakok, amikor a GDP-adatok kiegyenlítődést jeleznek két terület között, a társadalmi és egyéb puha tényezők terén viszont egyre nagyobb különbségek rajzolódnak ki (Barca 2009). A területek akkor fejlődnek, ha saját potenciáljukat - más néven: tőkéjüket - egyre hatékonyabban képesek kihasználni. A területi tőke új paradigmájával kapcsolatos értelmezések az 1990-es évek végétől jelentek meg a magyar szakirodalomban (Bodor, Grünhut 2014; Rechnitzer 2015; Tóth, Jóna 2013). A területi tőke fogalma a 2001-es OECD kiadvány megjelenése után vált 
általánosan elfogadottá. Az új meghatározás szerint minden terület rendelkezik speciális tőkével. E tőketényezők elkülönült, speciális csoportja vonzza az új tökebefektetéseket, illetve hozzájuk köthető a már működő befektetések gyorsabb megtérülése. Fontos megállapítás, hogy egy ország egy-egy területegysége speciális tőketényező-csoporttal rendelkezhet, amely elkülöníthető más területegységek tőketényezőitől. E speciális tőketényezők már megjelentek a különböző elméletekben (OECD 2001).

A fent leírtakból indult ki a Camagni-féle koncepció, amely meghatározta a területi tőke endogén jellegű összetevőit és azok viszonyrendszerét. Camagni 2005-ben már foglalkozott a területi tőke és a területi kohézió kérdéseivel, megállapítása szerint a területi tőkében a területi minőség és a területi hatékonyság összefüggenek egymással. Egy későbbi (Camagni 2008), szintén Camagni nevéhez füződő koncepció már abból indult ki, hogy előtérbe kerültek a kínálatorientált nézőpontok a területi tudományokban. E szempontok közül Camagni kiemelte a régiók közötti kereskedelemmel kapcsolatos versenyképességi elméleteket, amelyek szerint a régiók nem a komparatív előnyök révén versenyeznek, hanem sokkal inkább abszolút előnyök vagy versenyelőnyök alapján. Ezért a helyi és a regionális növekedési stratégiáknak fel kell tárniuk az adott terület azon belső értékeit, amelyek vonzóvá teszik a térséget a külső befektetők számára. A régiók, városok e helyi eszközeit és potenciáljait nevezi Camagni területi tőkének. A Camagni-féle értelmezés bármely területi szinten használható, és modellezi a városi, középvárosi, nagyvárosi, fővárosi, nemzeti és nemzetközi szinteken lévő anyagi és nem anyagi jellegű tőkekoncentrációkat. Felmerül a kérdés, hogy mi különbözteti meg ezt a területitőke-felfogást a hagyományos kínálatorientált felfogásoktól. A válasz az, hogy a hagyományos erőforrások (tőke, munkaerő, infrastruktúra) mellett a területi tőke olyan tényezőket is tartalmaz, amelyek az adott terület endogén fejlődését táplálják. Ilyenek az ipari parkokkal, az innovatív miliővel vagy a klaszteresedéssel kapcsolatos összefüggések, amelyek beépülnek a helyi atmoszféra és irányítás szinergiájába, és megjelennek a társadalmi és kapcsolati tőkében. Camagni területitőke-koncepciója az OECD által felsorolt strukturált tényezők osztályozását vette alapul, e tényezők a következők (OECD 2001):

- földrajzi elhelyezkedés,

- méret,

- a termelés szintje,

- klíma,

- tradíciók,

- természeti erőforrások,

- életminőség,

- üzleti inkubáció,

- ipari parkok,

- üzleti hálózatok,

- szokások, 
- informális szabályok,

- szolidaritás,

- közös támogatások,

- ötletek találkozása,

- környezet. ${ }^{3}$

A felsorolt fejlettségi összetevők párhuzamba állíthatók Camagni mátrixával (1. ábra). A kilenc csoportba sorolt tényezők hozzájárulnak egy-egy terület relatív és abszolút versenyelőnyéhez. (Giffinger, Haindlmaier, Kramar 2010).

Az 1. ábra négy sarkában találhatók a „hagyományos” elemek, a középen elhelyezkedő, szürke háttérrel jelölt négyzetek pedig az „innovatív keresztet” alkotják, ez utóbbira összpontosul Camagni figyelme. Az innovatív keresztben lévő tényezőkkel írható le egy-egy terület innovációs teljesítménye, tudásfelhalmozása és tudásteremtése, ezek a tudáshasznosítási folyamatok müködtetői és generálói, azaz egy térség kapcsolati tőkéjének és tanulási képességének jellemzői. A koncepció egyik újszerüsége éppen e tényezők kimutatása és felsorolása. E tényezők hozzák létre azt a miliőt, amelyben a szabad tudásáramlás kollektív tanulási folyamatokat eredményez (Camagni 2009).

1. ábra: A területi tőke komponenseinek elméleti rendszere Theoretical taxonomy of the components of territorial capital

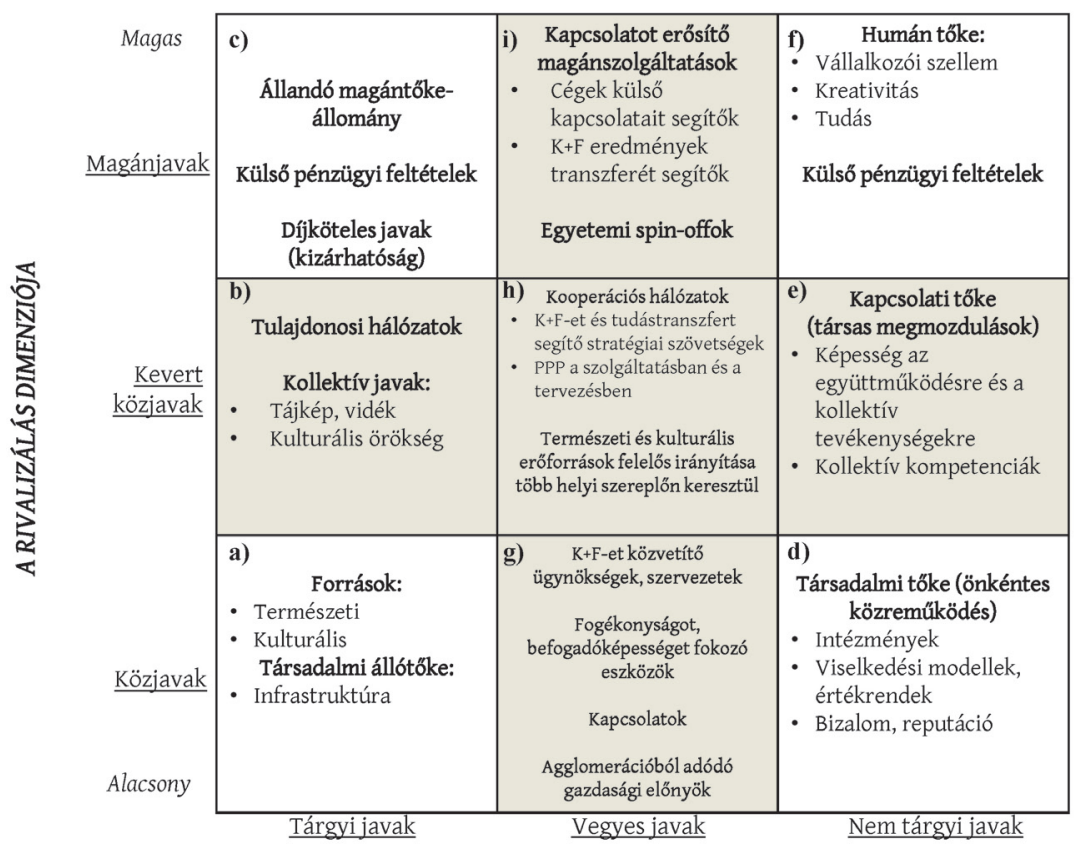




\section{Az innovatív kereszthez füződő megállapítások}

A tárgyi magán- és közjavakat, illetve a nem tárgyi humán és társadalmi tőkét, vagyis a "hagyományos” négyzetcsoportokat a köztük lévo „kereszt” innovatív csoportjai befolyásolják. Capello és szerzőtársai (2009) szerint az „innovatív kereszt” tőkecsoportjai „kötőanyagként” funkcionálnak, egymáshoz illesztik a „hagyományos" négyzetek négy tőkecsoportját. A területi tőke, a tudásáramlás és a gazdasági növekedés közti kapcsolatokat vizsgálva az az alapfeltevésük, hogy minél több megismerésen alapuló, kognitív tőketényező van jelen egy területen, annál értékesebb az adott terület tőkéje. Ez kihat a gazdasági növekedésre. A magyar szakirodalom is hangsúlyozza az „innovatív kereszt” értelmezésének jelentőségét. Egyes megállapítások - politikai szempontból - a „mi”-tudat erősödésének ábrázolásában, gazdasági szempontból pedig a vállalati együttmüködések és azok pozitív következményeinek ábrázolásában (Tóth 2013) látják az értékét. Ezzel párhuzamos értelmezések a koncepciót és a hozzá vezető elemzések eredményeit úgy értékelik, hogy a gazdaságilag fejlett területek esetében az „innovatív kereszt” tőketényezői felértékelődnek. Ennek az a magyarázata, hogy a „hagyományos” négyzetben lévő tényezők majdnem mindenhol rendelkezésre állnak (Nagyházi 2014), vagyis a „hagyományos” négyzet tényezőinek megléte nem elég ahhoz, hogy egy terület vállalati versenyelőnyei gyorsan növekedjenek, és ennek révén kedvezőbb gazdasági környezet vagy versenyelőny alakuljon ki. E célok eléréséhez olyan speciális tőketényezőkre van szükség, amelyek növelik a „hagyományos” négyzetben lévo tényezők hatékonyságát (Lengyel 2010). Más megállapítások hangsúlyozzák, hogy a lokális „innovatív keresztbeli” tényezők megjelennek a sikeres fejlesztéspolitikában. Mindemellett a területi tôke jelensége a térségben kialakult emberi relációkon, viselkedéseken és mintakövetéseken is alapul (Rechnitzer, Smahó 2011). A területi tőke koncepciója a társadalom állapotát, szerkezetét és egyenlőtlenségeit plasztikusan veti össze a gazdasági struktúrával (Jóna 2013a).

A Camagni-koncepció értelmezése kétféleképp különböztethető meg: leíró és normatív szempontból. A leíró értelmezés szerint a területi tőke - mint a megjelenítés eszközének - célja a területeken, térségekben lévő viszonyrendszerek felvázolása, szemléltetése. A normatív értelmezés szerint az is fontos, hogy a területek közötti szintkülönbségek is megjelenjenek, és ehhez kapcsolhatóak a területi tőke - mint méréshez használt eszköz - modellalkotási kísérletei (Jóna 2013b). A koncepciót felhasználva a területek fejlettségbeli különbségeinek empirikus kutatásai szintén megjelentek. A NUTS2 szintű felmérések anyagai alapján Camagni és Capello (2013) a regionális versenyképesség és a területi tőke közti kapcsolatot mutatják be. A koncepciót tesztelik és igazolják empirikus példákkal, különböző indikátorok használatával.

Ebben a tanulmányban a területi tőke koncepcióját mint a megjelenítés eszközét értelmezzük, tehát a leíró szempontokat követjük. Véleményünk szerint ehhez az elemzéshez kapcsolhatóak leginkább a területi tőke koncepciójának kiegészítő és kritikai megközelítései. 


\section{Kiegészítő és kritikai megközelítések}

A koncepcióval kapcsolatos kiegészítő megállapítások egyike szerint egy adott területre kívülről betelepülő gazdasági szereplo kezdetben a „hagyományos” négyzet tényezőire van hatással, és később ágyazódik be, azaz az „innovatív kereszt" tényezőire gyakorolt hatásai csak később mutatkoznak meg (Rota 2010). Egyetértünk azzal a kiegészítő megállapítással, hogy ki kell emelni a városi policentrikus fejlődést a területi tőke koncepciójában (Giffinger, Suitner 2010). A városi környezetben jobban kirajzolódnak és homogénebbek az „innovatív kereszt" egyes tényezői, például a vállalkozókészség, a magatartási minták vagy értékrendek. Vannak olyan - a kapcsolati tőke és a társadalmi tőke közti átfedésekről szóló - kritikai megállapítások, amelyek a területi tőke mátrixához egy harmadik dimenziót kapcsolnak. Ezt a dimenziót az abszolút és relatív tőketényezők alkotják. Az „innovatív keresztben” felsorolt tőkecsoportok relatíve értelmezendők (Bodor, Grünhut 2014). A magyar középvárosokra vonatkozó elemzés azt mutatta, hogy a területi tőke mátrixában felsorolt tőkeosztályok mellett más jellegü tőkéket is fel lehet használni a mérésekhez. E felfogás alapján készült átfogó felmérés rangsorolja a középvárosokat (Tóth 2013).

\section{Az innovatív kereszt tőkecsoportjainak értelmezése}

Ebben a fejezetben egy Győrre vonatkozó alkalmazott kutatás vállalati szintű vizsgálata alapján értelmezzük az „innovatív kereszt” tőkecsoportjait.

\section{Tárgyi, kevert közjavak (b)}

Tulajdonosi hálózaton egy terület köz- és magántulajdonban lévő hálózatait értjük. Példaként említhető egy belvárosi tér, ahol a helyi vállalkozók közterületet bérelnek vagy részben ingatlanokat tulajdonolnak. Az imént felsorolt javak köz- és magántulajdonban vannak. Ezek a győri járműipari körzetben működő vállalkozások fizikai értékei (épületek, raktárak, termelő eszközök) a vállalati kérdőívben. A tulajdonosi hálózatok kevésbé kapcsolhatók a kevert közjavak kategóriájához, bár területi szinten is a versenyképesség alkotóelemei közé tartoznak (Fiáth, Megyes 2010; Vedres 2000; Vitali, Glattfelder, Battiston 2011). A hálózatok több szempontból értelmezhetők (matematikai, szociológiai, pszichológiai, közgazdaságtani, fizikai, rendszerelméleti, biológiai és vállalati szektorban egyaránt) (Barabási 2003). Azt vizsgáltuk, hogy van-e a válaszadók között olyan vállalat, ahol megjelenik a közszféra és a magánszféra tulajdonosi rendszere. Győr esetében ez a város környékén elhelyezkedő kikötő és repülőtér volt. 


\section{Vegyes, magántulajdonban lévő javak (i)}

A kapcsolati magánszolgáltatások piaci szereplők által létrehozott kooperációk, melyek nem feltétlenül piaci alapúak. A látható és nem látható kapcsolati magánszolgáltatások a cégek külső kapcsolataihoz kötődnek. Emellett működhetnek a vállalkozások K+F-eredményeinek transzfere alapján is, amely szintén látható és nem látható formában jelenik meg. Ezeket hívja Camagni vegyes (hard és soft) tényezőket tartalmazó magánjavaknak. Camagni (2009) modellje a kapcsolatot erősítő magánszolgáltatásokat alcsoportokra osztja annak alapján, hogy milyen jellegü kapcsolatok erősödésében segítenek.

Cégek külső kapcsolatait segitó szolgáltatások: A kérdőívben a vállalatokat arról kérdeztük, hogy milyen közvetítő szervezeteket vesznek igénybe kapcsolataik növeléséhez, és hogy igénylik-e a tudáshoz való hozzáférést annak érdekében, hogy beszállítói vagy megrendelői kapcsolataikat javítsák. A kérdések között szerepel, hogy mennyire motiváltak annak érdekében, hogy olyan tudásra tegyenek szert, amelynek segítségével - a versenytársakkal együttműködve - piaci előnyhöz juthatnak, illetve hogy mekkora forrást fordítottak olyan lehetőségek kihasználására (pályázatok, egyéb támogatások), amelyek segítségével innovatív együttműködéseket (például beszállítói partnerkapcsolatok) kezdeményezhettek.

K+F-eredmények transzferét elősegítő szolgáltatások: Az ilyen transzferekből származó kapcsolati szolgáltatások piaci környezetben jönnek létre, ezért elsősorban a technológiai transzfert segítik. Példaként szolgálnak azok a profitorientált cégek, amelyek ellenérték fejében biztosítják az igényelt technológiát. A vállalati kutatásban olyan kérdések sorolhatóak ide, amelyek a K+F-eredmények keresletére vonatkoznak. Ezek a következők: Milyen mértékben végeztek vagy rendeltek meg másoktól K+F-tevékenységet? Hogyan változtak a K+F-költéseik? Milyen mértékben együttműködőek a vállalkozások a K+F és az innováció során? Milyen mértékben vonnak be partnereket az új ötletek megvalósításához? Mi az ezzel kapcsolatos jövőbeli tervük, véleményük?

\section{Vegyes, köztulajdonban lévö javak (g)}

K+F-et közvetitő ügynökségek, szervezetek: Camagni koncepciójában félig tárgyi, félig nem tárgyi elemeket tartalmazó közjavak alkotják a technológiatranszfert elősegítő ügynökségeket. Ez úgy értendő, hogy jórészt a közösségi javak járulnak hozzá egy terület nyitottságához, ezek növelhetik a terület adaptációs képességét. A közvetítö ügynökségek a K+F-eredmények átvitelében, átruházásában közreműködő eszközként funkcionálnak. A K+F-eredmények hasznosításán belül beszélhetünk technológiatranszferről. A Magyarországon működő regionális innovációs ügynökségek részben erre a célra jöttek létre. Kutatási eredmények felkarolásával, kisvállalkozói kapcsolatok erősítésével, 
projektek fejlesztésével a müködési hatáskörükben lévő terület versenyképességének javítását tűzik ki célul. A K+F-eredmények transzferét elősegítő ügynökségeken nemcsak a formálisan erre a célra létrehozott ügynökségeket értjük, hanem az azonos célú szervezeteket is. Ezek a szervezetek a regionális innovációs ügynökségek intézményi környezeti modelljében mellékszereplöként segítik egy adott terület tudásáramlását és K+F-szintjének növelését. A 2. ábrán (a téglalapokban) láthatók azok az intézmények, amelyek tevékenysége és céljai hozzájárulnak a területi innovációs folyamatok létrehozásához és innovációs szolgáltatások nyújtásához.

Mivel köztulajdonban lévő javakról van szó, az alkalmazott kutatásban olyan kérdések eredményei adhatnak értelmezési támpontokat, amelyek a felsőoktatással és a kutatóintézetekkel való együttmüködésre utalnak: Hol helyezkednek el azok az egyetemek és kutatóintézetek, amelyekkel a megkérdezett vállalkozások kapcsolatban állnak? Milyen tevékenységi körökre terjed ki a kapcsolatuk? Milyen mértékben működnek együtt az egyetemekkel és a kutatóintézetekkel? Ha nincs vagy gyenge az együttműködés, akkor milyen okokban látják az akadályozó tényezőket?

\section{2. ábra: Regionális innovációs ügynökségek intézményi környezete Institutional environment of regional innovation agencies}

1. Információs szint

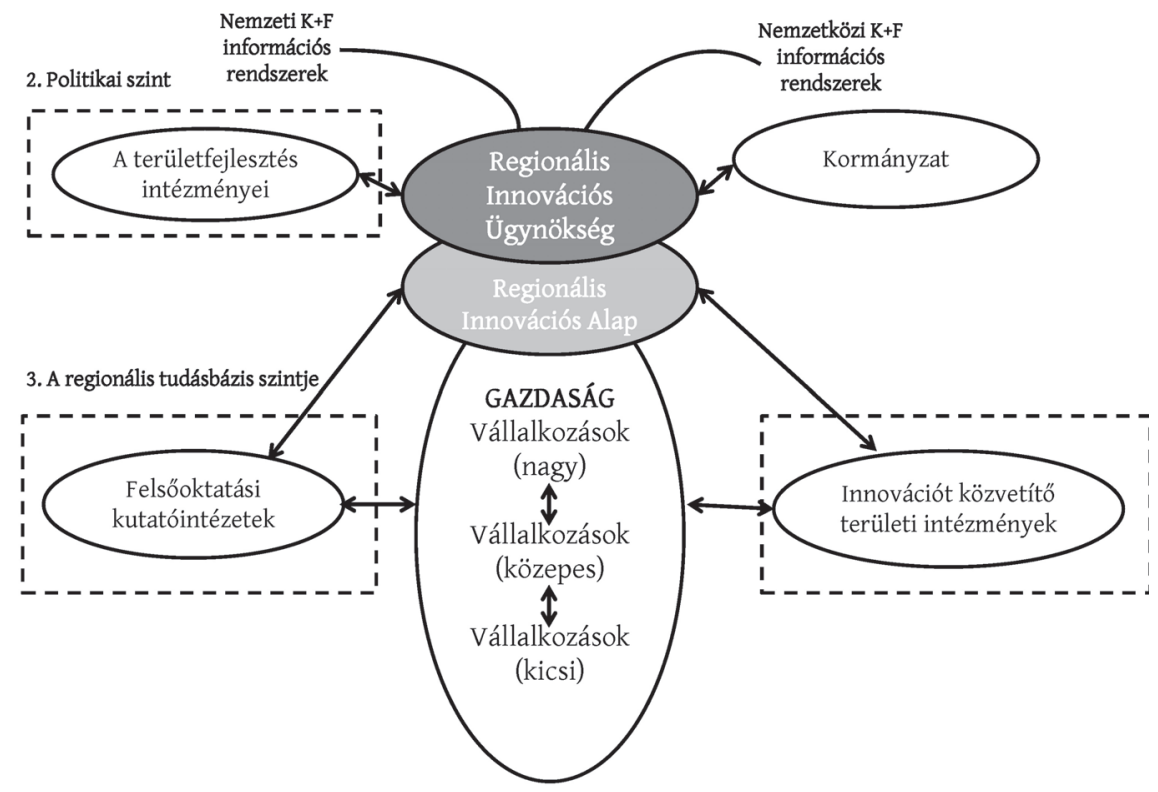

Forrás: Dőry (2005). 


\section{Nem tárgyi, kevert tulajdonú javak (e)}

A vállalatok és a közösségi intézmények készségét a nyitottságra és az együttmüködésre ki lehet mutatni a kapcsolati tőke megjelenésében is egy adott térségben. A kapcsolati tőke tartalmi meghatározása közel áll a társadalmi tőkéhez, ez utóbbi - Camagni koncepciója szerint - minden társadalomban jelen van. A kapcsolati tőke úgy is felfogható, mint a helyi szereplők által létrehozott két- vagy többoldalú kapcsolatok sora. Ezek olyan miliően jönnek létre, ahol erős a bizalom, azonos viselkedési modellek és értékek alakultak ki, a kapcsolatok kölcsönösek (Camagni 2008). A kapcsolati tőkének számos pozitív hatása van a többi tőketényező-csoportra. A kollektív tanulásból adódó kollektív kompetenciák hozzájárulnak az adott területen kialakuló érdekharmóniához, az érdekközösségek pedig gazdasági és stratégiai fellendüléshez vezethetnek. (Bodor, Grünhut 2014; Jóna 2013b). Például ha a helyi elit csoportjainak - a politikai és gazdasági vezetőknek, intézményvezetőknek, a cégtulajdonosoknak és a többi véleményformáló személynek - a jövőt formáló fejlesztési irányokkal kapcsolatos elképzelései nem ismertek, akkor az elitcsoportok között is kisebb a konszenzus. Az eltérő vagy esetlegesen széthúzó irányú elképzelések a terület fejlődését, a stratégiai törekvések megvalósítását gátolhatják. Vállalati szinten ugyanez a helyzet egy cég tudatos, bottom-up irányú fejlesztésében. Ha a vállalkozó a munkatársaitól megköveteli a cég gazdasági és társadalmi beágyazódását segítő kompetenciákat, illetve kiépíti a vállalaton belüli intenzív tudásáramlást, akkor ez a vezetői felfogás a vállalkozást nyitottá formálhatja. Ebben a vállalati környezetben a dolgozók kinyilváníthatják a véleményüket, és kevésbé korlátozott az információáramlás.

Képesség az együttmüködésre és a kollektív tevékenységekre: Győr és térségének innovációs szintje és tudásáramlása függhet a területen végbemenő együttmüködési folyamatoktól és a kollektív tevékenységek mértékétől. A kollektív tevékenységek koordinálása, felülről jövő, közösségi szintű ösztönzése és elemzése kulcskérdés. A kollektív tevékenység - amelyben több ember vesz részt egy helyen és egy időben - kialakulhat külső és belső késztetésre (Choi, Shahid, Savarese 2011). A kollektív tevékenységek jelenléte és gyakorisága a vállalkozás - jelen esetben a győri járműipari körzet területén működő vállalkozások - által támogatott programok, a közösségi aktivitást eredményező események. Az erre vonatkozó kérdések utalnak arra, hogy milyen arányban és milyen ügyeket, társadalmi célokat támogatnak a vállalkozások, illetve tervezik-e a támogatást.

Kollektív kompetenciák: A kollektív kompetenciák mérése gyakran kapcsolódik az oktatáshoz. A vállalkozások humánerőforrás-részlegei kiépült kollektív stratégiával rendelkeznek (Retour, Croquette 2003). Ennek mérésére módszertanilag legmegfelelőbb a mélyinterjú, amelyben lehetőség van a stratégia egyes részeinek kibontására, illetve a területfejlesztési szempontok megismerésére. A kérdések arra vonatkoznak, hogy milyen kapcsolódást elősegítő kompetenciákat követel meg a vállalat és milyen mértékben, vagy hogy a megkérdezett milyen kiterjedésben érzékeli az őt körülvevő környezetben a tudásáramlást. 


\section{Vegyes, kevert tulajdonú javak (h)}

A kooperációs hálózatok olyan csoportot alkotnak, amelyek összekötik a tárgyi és nem tárgyi javakat, illetve a magán- és közjavakat. Az innováció hálózatalapú megközelítése szerint a kooperációs hálózatoknak van a legjelentősebb szerepe a tudás újraelosztásában (Csizmadia 2004). A területi tőke koncepciójában (1. ábra) ez a csoport az ,innovatív kereszt” közepén helyezkedik el, tehát magában foglalja és összeköti a tárgyi és a nem tárgyi javakként, valamint a köz- és magánjavakként értelmezhető tőketényezőket. A profitot eredményező termékek és szolgáltatások a köz- és a magánszféra, illetve a magán- és a magánszféra együttműködései által jönnek létre. A kutatási kérdések a következők: Milyen mértékben támogatja egy vállalkozás a más vállalatokkal együttműködést eredményező kezdeményezéseket? Mennyire vesz részt a különböző együttműködési formákban? Ezeknek az együttmúködési formáknak mekkora a kiterjedése?

\section{A felmérés eredményei}

A győri járműipari körzet vállalkozásaira vonatkozó kérdőíves kutatás eredményei közül azokat emeljük ki, amelyeket az „innovatív kereszt” tényezőinek értelmezéséhez használtunk. Győr város gazdaságának fejlődése nagymértékben a jármüiparhoz kapcsolódik, a helyi gazdaság együttműködési rendszerei jelentősen hozzájárultak ehhez a folyamathoz. Hasonló - más európai térségekben végzett - járműipari vizsgálatokat is tudtunk hasznosítani kutatásunk során (Fekete 2014a, 2014b). A győri járműipari körzet vállalati kérdőíves felmérésének elsődleges célja nemcsak a területi tőke mérési módszereinek tesztelése volt, hanem más, a vállalkozások nyitottságával, a tudásteremtéssel és az innovációval kapcsolatos kérdések megválaszolására is kísérletet tettünk. A lekérdezés egy tudományos projekt keretében történt, ${ }^{4}$ amelynek célja volt a győri ipari körzet müködésének vizsgálata, és esetleg egy új típusú, térségi szintủ tervezési és fejlesztési rendszer kidolgozása (Rechnitzer 2013). A projekt lezárása után is folytatódott a témával kapcsolatos kutatási tevékenység. A kutatás Győrre és közvetlen környékére, Mosonmagyaróvárra és vonzáskörzetére, a Fertő-Rábaközre (Sopron város kivételével) terjedt ki, és további olyan vállalatokat is bevontunk a vizsgálatba, amelyek a győri járműiparhoz kapcsolódnak. ${ }^{5}$ A kutatásban 240 cég vett részt. Emellett nem tekinthető a kutatásunk reprezentatívnak. Úgy véltük azonban, hogy a kis mintaszámon végzett kutatásunk is segített kérdéseink megválaszolásában, és alkalmas arra, hogy az átfogó statisztikai elemzések eredményeit kiegészítse, pontosítsa, valamint hogy az „innovatív kereszt” tökeértékeinek megjelenését szemléltethesse a gyakorlatban.

Az általános információkat összefoglalva a 240 vállalkozás alapítási éve 1856-tól 2013-ig terjed. 116 vállalkozásnak Győrben, 89-nek más városokban, 
34-nek pedig községekben van a székhelye. A válaszadó vállalkozások formája 80\%-ban korlátolt felelősségű társaság. Az átlagos, 2012. évi árbevételük 751 millió forint, ezen belül a válaszadók 66\%-ánál 500 millió forint alatti, 34\%-ánál pedig 500 millió forint feletti a 2012. évi árbevétel. A vállalkozások átlagosan 34 főt foglalkoztatnak. Saját, önálló termékkel vagy speciális, egyedi szolgáltatással 29\%-uk rendelkezik. Az „innovatív kereszt” értelmezéséhez használt ismérvek: a cégek csaknem 88\%-ában nincs külföldi résztulajdon, 9\%-ában viszont teljes a külföldi tulajdonlás. Ez az arány jóval alacsonyabb az országosnál. (2011-ben a KSH 2012 és 2013-as kimutatása szerint Magyarországon a regisztrált vállalkozásoknak 30\%-a volt külföldi irányítás alatt álló múködő leányvállalat.) A kutatásban szereplő külföldi érdekeltségü vállalkozások kiemelkedő arányban köthetőek Ausztriához (38\%) és Németországhoz (26\%). A többi külföldi tulajdonú vállalat francia, olasz, svájci (8-8\%), holland, izraeli és luxemburgi (4-4\%) kötődésű.

\section{Tulajdonosi hálózatok}

Győr esetében nagyobb vállalatoknál figyelhető meg a magán- és közszféra vegyes tulajdonlási modellje. Példaként említhető a város környékén elhelyezkedő kikötő és repülőtér. A Győr-Gönyű kikötőt a Győr-Gönyű Kikötő Zrt. üzemelteti, részben önkormányzati tulajdonú, részben pedig az Audi Hungária Motor Kft. tulajdona. Az önkormányzat az 1990-es évek óta foglalkozik a kikötő fenntartásával és folyamatos fejlesztésével. Az Audi Hungária Motor Kft. számos nagy volumenű fejlesztésben vett részt. A Győr-Pér repülőtér 1994 előtt a Magyar Honvédség tulajdonában füves repülőtérként üzemelt. A repülőtér jelenleg 40\%-ban a Győr Megyei Jogú Város Önkormányzatának tulajdonában és 12\%-ban a magyar állam tulajdonában van. 2013-ban a repülőtér tulajdonosi köre kibővült az Audi Hungária Services Zrt.-vel. Mindkét példa azt szemlélteti, hogy a magántulajdonosi szféra a nagyobb fejlesztések megvalósításánál szállt be a tulajdonosi körbe.

\section{A cégek külső kapcsolatai és a K+F-transzfert segítő szolgáltatások}

A cégek külső kapcsolatai és K+F-transzfert segítő szolgáltatások kérdései arra vonatkoztak, hogy milyen irányokban motiválja a vállalatokat a tudáshoz való hozzáférés: munkaerőt kívánnak átcsábítani, vagy a versenytársakkal, beszállítókkal, megrendelőkkel és felsőoktatási intézménnyel igyekeznek együttmüködni, vagy éppen a klaszteresedés folyamatának résztvevőivé akarnának válni. A válaszok megoszlása a 3. ábrán látható.

A tudáshoz való hozzáférés elsősorban az együttmüködés érdekében motiválja a vállalkozásokat. Legnagyobb arányban a beszállítókkal és a megrendelőkkel való együttmüködések reményében keresik a tudást, de a versenytársakkal 
3. ábra: Vállalatok tudáskeresletének motiváló tényezői

Motivators in corporate need of knowledge

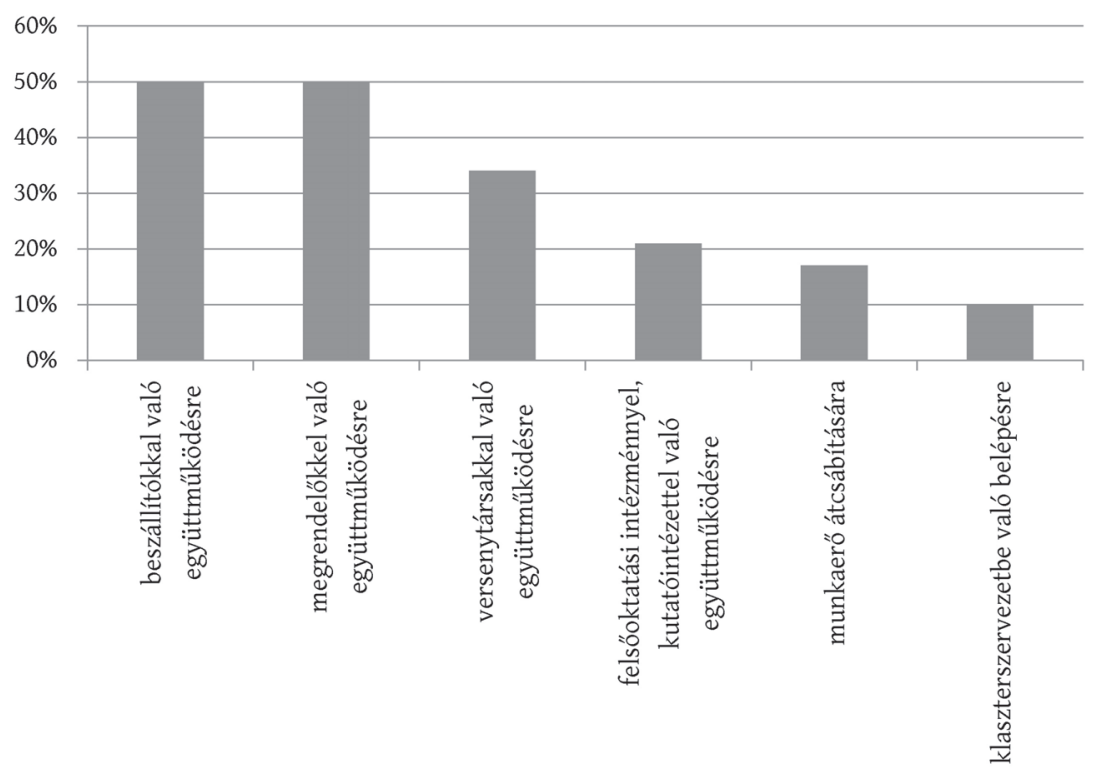

való együttműködés igénye is magas értékeket mutat. A kérdőíves vizsgálat tartalmaz olyan eredményeket is, amelyek a vállalkozásokat érintő támogatásokkal voltak kapcsolatosak. A vállalkozások hazai vagy EU-s támogatásokkal kapcsolatos információi azt mutatták, hogy az együttműködést kezdeményező pályázatok segítették a beszállítói hálózat formálódását, illetve a klaszteresedést. Ezeknek a jelenségeknek szintén vannak tárgyi és nem tárgyi területi értékei, ezt mutatta a cégek külső kapcsolatainak megerősödése vagy a K+F-eredmények beáramlása. (A kérdésre 100\%-os volt a válaszadási arány, a 2010 és 2012 között támogatást kapó vállalkozások aránya 37\% volt.) A 4. ábra a támogatások megoszlását mutatja.

Azok a vállalkozások, amelyek részesültek támogatásban, az összeget elsősorban az innovációs tevékenységhez szükséges épületek, infrastruktúrák létrehozására, illetve gépek, berendezések, eszközök vásárlására fordították. Azok a vállalkozások, amelyek együttmüködéseket elősegítő támogatásokat kaptak, azonos arányban számoltak be egyetemekkel, más vállalatokkal és civil szervezetekkel való együttműködésekről. A K+F-eredmények transzferén alapuló magánszolgáltatásokhoz kapcsolódnak azok a felmérési eredmények, amelyek a vállalkozások K+F-költéseit összekötik a külső partnerek bevonásának mértékével. A 2010-2012-es időszakban a vállalkozások közel 10\%-a végzett vagy rendelt meg kutatás-fejlesztési tevékenységet és árbevételük 4\%-át fordították átlagosan K+F-re. Az országos adatok szerint 2010 és 2012 között a K+F-intenzitás növekedett (KSH 2013). Ez a tendencia a kérdőíves eredményeinkkel is igazolható. 
4. ábra: A támogatott vállalatok aránya a $\mathrm{K}+\mathrm{F}$, az innováció és az együttműködés területein Share of supported companies in the field of cooperation

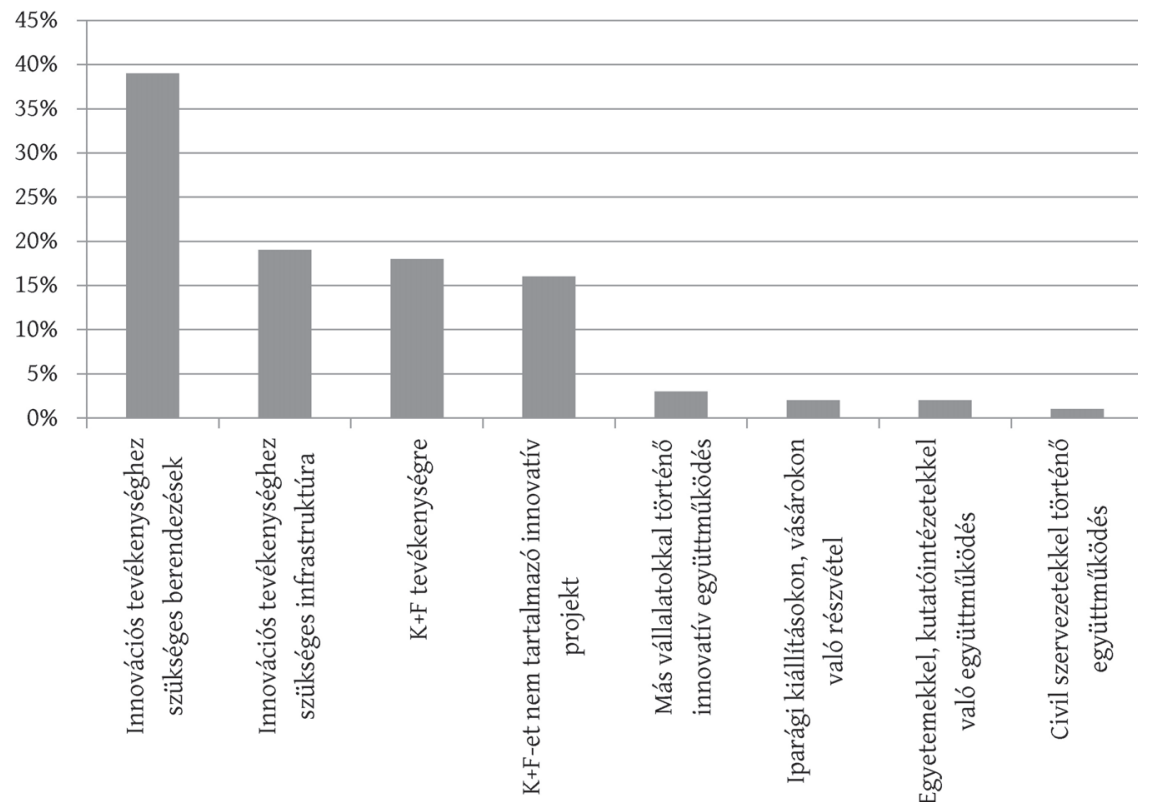

\section{Kutatást és fejlesztést közvetítö ügynökségek és szervezetek}

A regionális innovációs ügynökségek környezeti modelljében (2. ábra) látható a vállalkozások és a felsőoktatási intézmények és egyéb kutatóintézetek kapcsolata, ezt a kapcsolatot mi is vizsgáltuk (1. táblázat).

A válaszadó vállalkozásokkal csak belföldi egyetemek és főiskolák állnak kapcsolatban, a vállalkozók közepes mértékűnek tartják az együttműködést. Az együttműködést akadályozó tényezők között főleg a vállalat tudásbefogadási képességét, a potenciális partnerszervezet abszorpciós kapacitását, a vállalat tudásátadási hajlandóságát, a korszerű menedzsmentismeretek hiányát, a vállalati és a pályázati források hiányát említették. Alig hivatkoztak a bizalomhiányra, a vállalatvezetés szemléletmódjára és a vállalati kultúrára. Ez azt a további következtetést vonhatja maga után, hogy a válaszadók többségének már nagy tapasztalata van az egyetemekkel és kutatóintézetekkel való együttműködések terén, konkrét okokat, gyengeségeket tudnak megnevezni. A felsőoktatási-vállalati együttműködések további elemzése és fejlesztése szempontjából ez az eredmény kulcsfontosságú lehet. 
1. táblázat: A vállalkozások felsőoktatási intézményekkel és egyéb kutatóintézetekkel való kapcsolatának földrajzi kiterjedése Geographic scope of knowledge based corporate cooperation

\begin{tabular}{lc}
\hline \multicolumn{1}{c}{ Térbeli elhelyezkedés } & Kapcsolatok száma \\
\hline Helyben (a cégtól max. fél órára) & 14 \\
Észak-Dunántúl távolabbi területei & 8 \\
Budapest és környéke & 4 \\
Máshol az országban & 3 \\
Bécs & 0 \\
Ausztria határhoz közeli részei & 0 \\
Pozsony & 0 \\
Szlovákia határhoz közeli részei & 0 \\
Máshol & 0 \\
\hline
\end{tabular}

\section{Kollektiv tevékenység és kollektív kompetenciák}

A vállalkozások kollektív tevékenységére utaló válaszok alapján a többség (84 válaszadó) egyértelműen sporteseményt vagy sportrendezvényt és családi rendezvényeket támogat (5. ábra). A legtöbben az elmúlt 5 évben 500 ezer és 1 millió forint közötti értékben támogatták az 5. ábrán látható területeket.

5. ábra: A vállalkozások által támogatott programok és szolgáltatások (jelenleg támogató vagy a támogatást tervező vállalkozások száma) Collective programs and services supported by companies

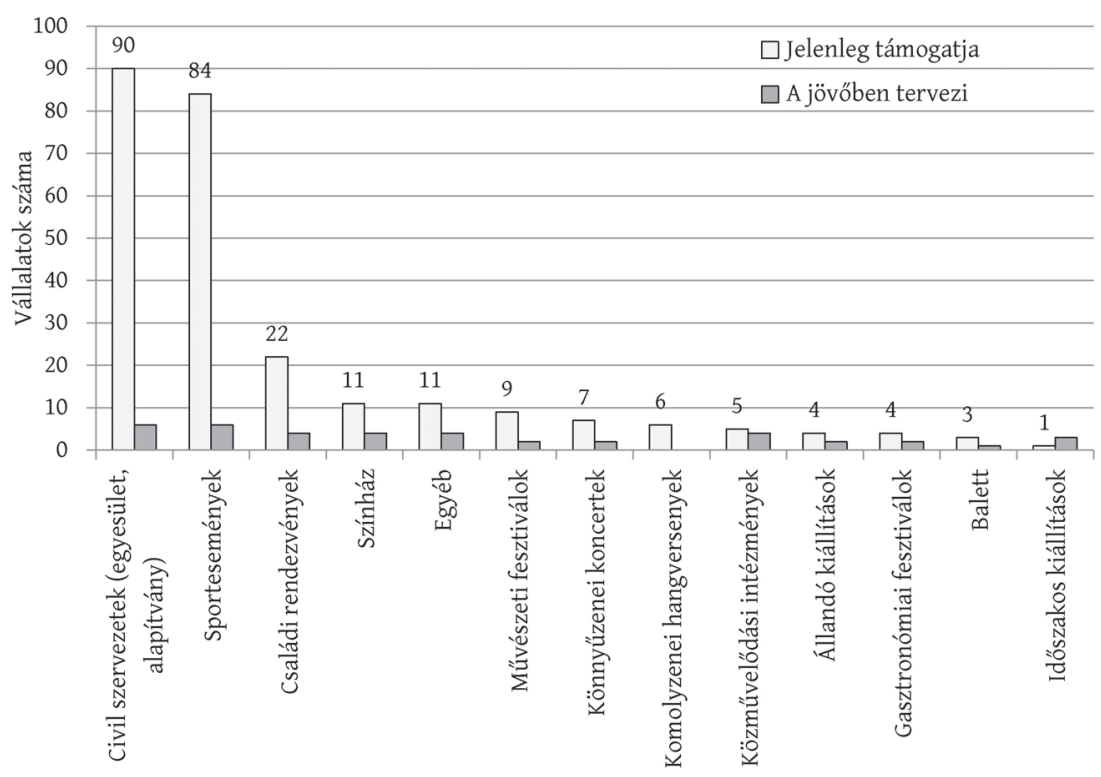


A vállalati dolgozók nyitottságát mint kollektív kompetenciát is mértük. A 240 vállalkozás $92 \%$-ában megfogalmazódott, hogy minden dolgozójától megköveteli a nyitottságot, a válaszok 5\%-ában a vállalkozások csak bizonyos dolgozóiktól követelik meg a nyitottságot, 3\%-ában pedig egyáltalán nem várják el mint munkakörhöz kapcsolódó készséget. A 6. ábra mutatja, hogy a vállalkozások 70-80\%-a saját környezetében nem érzékel tudásáramlást. A többi válasz szerint iparágon belül jelenik meg a tudásáramlás (15-20\%). A vállalkozások a piaci tudástranzakciót nagyobb arányban választották, mint az informális tudásáramlást.

6. ábra: A vállalkozás környezetében érzékelt tudásáramlás és tudástranzakció

Companies' perception of knowledge transaction and transfer

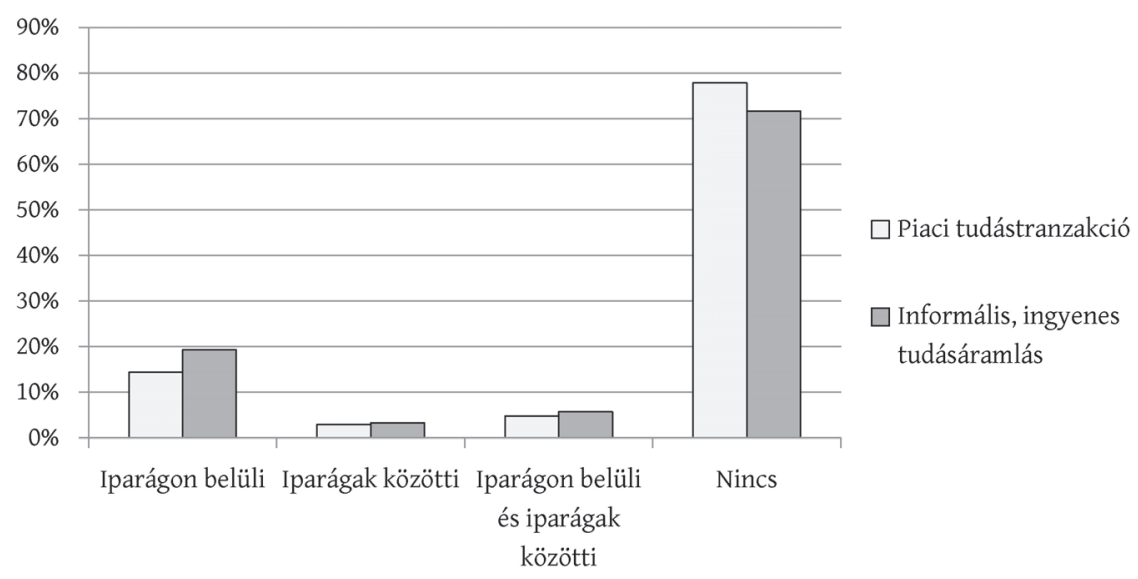

\section{Kooperációs hálózatok}

A kooperációs hálózatokhoz kapcsolódó kérdésekre szinte minden megkérdezett válaszolt. A 2010-2012-es időszakban a vállalkozások 6\%-a vett részt klaszterszervezetben, leginkább lokálisan (a cégtől maximum fél órán belüli távolságban), illetve Budapesten és agglomerációjában. A válaszadók 3\%-a kapcsolódott stratégiai szövetséghez, 7\%-a pedig nagyobbrészt szintén helyi konzorciális együttmüködéshez. Legnagyobb arányban (30\%) szakmai szövetségekben vettek részt a vállalkozások. Ez jórészt a Győr-Moson-Sopron Megyei Iparkamarának köszönhető.

\section{Összegzés}

A tanulmány célja az volt, hogy az „innovatív keresztben” lévő tőkeértékek megjelenési formáit szemléltesse a városi környezetben tevékenykedő vállalko- 
zói rétegben. A győri járműipari körzet vállalkozásairól szóló vizsgálat a tulajdonosi szerkezetek, a külső kapcsolatok erőssége, a K+F-transzfert segítő szervezetek igénybevétele, a kooperációs hálózatokban való részvétel szempontjaira fókuszált. A kutatás eredményei inputokat adhatnak a jövőben tervezett fejlesztésekhez. A pilot jellegű lekérdezés eredményei természetesen elsősorban arra szolgálhatnak, hogy a statisztikai elemzések eredményeit kiegészítsék, pontosítsák. A vegyes tulajdonban lévő vállalatokhoz, szervezetekhez a magántulajdonosi kör a nagyobb volumenű fejlesztéseknél kapcsolódott. Győr jármüipari körzetében vizsgált vállalkozások tudáshoz való hozzáférésének legfőbb motivációja az együttmüködés bővülése. A megkérdezett vállalatok viszonylag kis hányada részesült eddig együttműködéseket célzó támogatásokban, ez viszont nem jelenti, hogy a vállalatok érdeklődése gyenge a kooperációkat elősegítő információk iránt. A felsőoktatási intézményekkel és kutatóintézetekkel, illetve a K+F-eredmények transzferét elősegítő ügynökségekkel való együttmüködési hajlandóságuk átlagos értéket mutat. A győri járműipari körzetben müködő vállalkozások K+F-kiadásai azonos trendet mutatnak az országos adatokkal. A válaszadó vállalkozásokkal csak belföldi egyetemek és főiskolák állnak kapcsolatban, elsősorban a $\mathrm{K}+\mathrm{F}$ és az innováció terén. A válaszadók többsége már komoly tapasztalatokkal rendelkezik. Az egyetemekkel és a kutatóintézetekkel való együttmüködések hiányával kapcsolatban konkrét okokat, gyengeségeket tudnak megnevezni, amelyeknek a kiküszöbölése fontos szempont lehet a közös fejlesztésekben. A vállalkozások a közösségi együttműködések közül legszívesebben sporteseményeket, sportrendezvényeket és családi rendezvényeket támogatnak.

Camagni koncepciójával kapcsolatban az a véleményünk, hogy a vizsgált helyzet egyediségéhez igazítva ad elméleti kiindulópontokat. A tanulmányban összekapcsoltuk a győri vállalati réteg endogén elemeit a területi tőkeértékekkel és azok értelmezésével. Az empirikus megközelítésben nyilvánvalóvá vált, hogy nem lehetett minden elemet pontosan beleilleszteni a Camagni által kijelölt csoportokba. Ennek oka nem feltétlenül a használt változók hiányosságaiban keresendő, hanem a koncepciónak az empirikus alkalmazás során tanúsított „ellenállásából”.

\section{Jegyzetek}

1 Alapítva: 1896, jogutód: Rába Járműipari Holding Nyrt.

2 Zonnenveld és Waterhout $(2005,2010)$ megállapították, hogy minden területnek sajátos tőkekészlete van, amelyekben vannak kemény és puha tényezők.

3 A környezet mint összetevő értelmezése Alfred Marshall megállapításai alapján értendő: „valami van a levegőben"; költségcsökkentő mechanizmusok, amelyek a közelségen alapulnak; adott területen lévő szervezetek, szabályzatok, gyakorlatok, termelők, kutatók és jogszabályalkotók kombinációjának eredménye. 
„Győr Járműipari Körzet, mint a térségi fejlesztés új irányai és eszköze” TÁMOP-4.2.2.A11/1/KONV program.

5 A kutatási területet a program ezen a módon határolta le.

\section{Irodalom}

Bajmócy Z. (2011): Bevezetés a helyi gazdaságfejlesztésbe. JATEPress, Szeged

Barabási A. L. (2003): Behálózva. Helikon Kiadó, Budapest

Barca, F. (2009): An agenda for a reformed cohesion policy, A place-based approach to meeting European Union challenges and expectations. http://www.europarl.europa.eu/meetdocs/2009_2014/ documents/regi/dv/barca_report_/barca_report_en.pdf (Letöltés: 2015. szeptember 23.)

Bodor Á., Grünhut Z. (2014): Dilemmák a területi tőke modelljének alkalmazhatóságáról, A társadalmi tőke problémája Camagni elméletében. Tér és Társadalom, 3., 3-18.

Camagni, R. (2005): The rationale for territorial cohesion: issues and possible policy strategies. In: Boscaino, P. (ed.): Present and future of the European spatial development perspective. Alinea, Firenze, 121-138.

Camagni, R. (2008): Towards a concept of territorial capital. In: Capello, R., Camagni, R., Chizzolini, B., Fratesi, U. (eds.): Modelling regional scenarios for the enlarged Europe. Springer, Berlin, 33-48. http://doi.org/cj7qfq

Camagni, R. (2009): Territorial capital and regional development. In: Capello, R., Nijkamp, P. (eds.): Handbook of regional growth and development theories. Edward Elgar, Northampton, 118-132. http://doi.org/4hv

Camagni, R., Capello, R. (2013): Regional competitiveness and territorial capital: A conceptual approach and empirical evidence from the European Union. Regional Studies, 9., 1383-1402. http://doi.org/bcj9

Capello, R., Caragliu, A., Nijkamp, P. (2009): Territorial capital and regional growth: Increasing returns in cognitive knowledge use. https://www.econstor.eu/dspace/bitstream/10419/86826/1/09-059.pdf (Letöltés: 2015. december 12.)

Choi, W., Shahid, K., Savarese, S. (2011): Learning context for collective activity. Recognition, Department of Electrical and Computer Engineering, University of Michigan. http://www.eecs.umich.edu/vision/papers/cvpr2011choishahid.pdf (Letöltés: 2015. december 11.)

Csizmadia Z. (2004.): Az innováció hálózati alapú megközelitése, Tudásáramlás, innovációs rendszerek, regionális hálózatok. http://www.socialnetwork.hu/cikkek/CsizmadiaZoltanInnovacioMunkakozi1.pdf (Letöltés: 2015. szeptember 12.)

Czakó K. (2015): Diskurzus a területi tőke koncepciójáról. Tér és Társadalom, 4., 176-186. http://doi.org/bckb

Dőry T. (2005.): Az innovációk regionális szintű alakításának irányai. In: Rechnitzer J., Grosz A. (szerk.): Régiók és nagyvárosok innovációs potenciálja Magyarországon. MTA RKK, Pécs, 273-294.

Fekete D. (2014a): Gazdaságfejlesztés az ingolstadti jármüipari központban. Tér és Társadalom, 2., 176-187.

Fekete D. (2014b): Nagyvárosi kormányzás és gazdaságfejlesztés a Rhein-Neckar nagyvárosi régió példáján. Köztes Európa: Társadalomtudományi folyóirat: A VIKEK közleményei, 6., 91-98.

Fiáth A., Megyes J. (2010): A hálózatos iparágak szabályozási környezete. Vezetéstudomány, 41., 4-11.

Giffinger, R., Suitner, J. (2010): Danube Region Strategy - Arguments for a territorial capital based multilevel approach. Spatium, 23., 9-16. http://doi.org/cv8m2p

Giffinger, R., Haindlmaier, G., Kramar, H. (2010): The role of rankings in growing city competition. Urban Research and Practice, 3., 299-312. http://doi.org/fcnf4z

Jóna Gy. (2013a): A területi tőke fogalmi megközelítései. Tér és Társadalom, 1., 30-51.

Jóna Gy. (2013b): A területi tőke kistérségi jellegzetességei. Doktori (PhD) értekezés. Enyedi György Regionális Tudományok Doktori Iskola, Gödöllő. https://szie.hu//file/tti/archivum/ 
Jona_Gyorgy_ertekezes.pdf (Letöltés: 2015. december 20.)

KSH (2012): Regisztrált társasági szervezetek száma. 2011. Statisztikai Tükör, 19., http://www.ksh.hu/docs/hun/xftp/gyor/gaz/gaz21112.pdf (Letöltés: 2015. december 11.)

Lengyel I. (szerk.) (2010): Regionális gazdaságfejlesztés. versenyképesség, klaszterek, alulról szerveződő stratégiák. Akadémiai Kiadó, Budapest

Lengyel I., Szakálné Kanó I., Vas Zs. (2015): Regionális klaszterek és agglomerációs előnyök: feldolgozóipar a magyar városrégiókban. Tér és Társadalom, 3., 49-72. http://doi.org/bckc

Nagyházi Gy. (2014): Belső erőforrásokat mozgósitani képes területfejlesztési politika lehetőségei. Tervezett disszertáció, SZE, Regionális és Gazdaságtudományi Doktori Iskola

OECD (2001): OECD Territorial Outlook, Territorial Economy. http://www.vwl.tuwien.ac.at/ hanappi/AgeSo/SecReps/Territorial_Outlook_F.pdf (Letöltés: 2015. december 10.)

Porter, M. E. (1985): Competitive advantage. Free Press, New York

Rechnitzer J., Smahó M. (2011): Területi politika. Akadémiai Kiadó, Budapest

Rechnitzer J. (2013): A Győri Jármüipari Körzet, mint a térségi fejlesztés új iránya és eszköze. TÁMOP-4.2.2.A11/1/KONV azonositószámú pályázat keretében elvégzett kutatás. Kutatási terv. Széchenyi István Egyetem, Győr

Rechnitzer J. (2015): Területi tóke szerepe a városfejlődésben - A Győr kód. MTA RKK, Pécs, kézirat (megjelenés alatt)

Retour, D., Croquette, D (2003): Gestion des compétences et stratégie d'entreprise. Personnel, 1., 2-34.

Rota F. S. (2010): The territorial embedment of global industrial networks, Evidences from foreign multinational companies in Turin. Proceedings of the Regional Studies Association (RSA), International Conference, Pécs

Tóth B. I. (2013): A területi tőke szerepe a regionális- és városfejlődésben, esettanulmány a hazai középvárosok példáján. Doktori értekezés, Nyugat-magyarországi Egyetem, Sopron

Vedres B. (2000): A tulajdonosi hálózatok felbomlása: A rekombináns tulajdonformák szerepe és a hazai nagyvállalatok tulajdonszerkezetének jellemzői a 90-es évek végén. Közgazdasági Szemle, szeptember, 680-699.

Vitali, S., Glattfelder, J. B., Battiston, S. (2011): The network of global corporate control, Plos-one, http:// journals.plos.org/plosone/article?id=10.1371/journal.pone.0025995 (Letöltés: 2015. december 13.)

Zonneveld, W., Waterhout, B. (2005): Visions on territorial cohesion. Town Planning Review, 1., 15-27. http://doi.org/fj9d73

Zonneveld, W., Waterhout, B. (2010): Implications of territorial cohesion: an essay. Paper prepared for the Regional Studies Association Annual International Conference, Pécs http://www.esponinterstrat.eu/admin/attachments/Zonneveld.pdf (Letöltés: 2015. október 1.)

http://www.ksh.hu/docs/hun/eurostat_tablak/tabl/tsc00001.html (Kutatás-fejlesztési ráfordítások szektoronként a GDP százalékában.) (Letöltés: 2015. december 31.)

http://statinfo.ksh.hu/Statinfo/haViewer.jsp (Magyarországon működő külföldi irányítású leányvállalatok statisztikája) (Letöltés: 2015. december 21.) 